\title{
BACTERIOCINOGENIC POTENTIAL OF LACTIC ACID BACTERIA ISOLATED FROM ARTISANAL COLONIAL TYPE-CHEESE
}

\section{(Potencial bacteriocinogênico de bactérias ácido-láticas isoladas de queijo artesanal tipo colonial)}

\author{
Kadigia Pegoraro ${ }^{1}$, Mallu Jagnow Sereno ${ }^{2}$, Valéria Quintana Cavicchioli ${ }^{2}$, Cibeli Viana ${ }^{2}$, Luís Augusto \\ Nero $^{2}$, Luciano dos Santos Bersot ${ }^{1}$ \\ ${ }^{1}$ Universidade Federal do Paraná, Setor Palotina, ${ }^{2}$ Universidade Federal de Viçosa,
}

Corresponding author: lucianobersot@gmail.com

\begin{abstract}
Autochthonous microbiota from artisanal cheeses is predominantly composed of lactic acid bacteria (LAB), which are able to produce antimicrobial compounds, such as bacteriocins, suggesting their application in food biopreservation. Knowledge about LAB growth and bacteriocin production during food production and conservation is essential to determine their use. In this way, the study aimed at isolating bacteriocinogenic LAB from twenty-one artisanal Colonialtype cheeses obtained from the western region of Parana state, Brazil, determining the best conditions for growth and bacteriocin production $\left(25^{\circ} \mathrm{C}, 30^{\circ} \mathrm{C}\right.$, and $\left.37^{\circ} \mathrm{C} / 24 \mathrm{~h}\right)$; bacteriocin stability under different ranges of $\mathrm{pH}(2,4,6,8$, and 10 for $2 \mathrm{~h})$ and temperature $\left(60^{\circ} \mathrm{C} / 2 \mathrm{~h} ; 80^{\circ} \mathrm{C} / 2 \mathrm{~h} ; 121^{\circ} \mathrm{C} / 15 \mathrm{~min}\right)$. Their activity against different target microorganisms was also evaluated. A total of 34 LAB strains presented characteristics compatible with bacteriocin production. Most of them presented better results for bacteriocin production when cultured at $25^{\circ} \mathrm{C}$ and $30^{\circ} \mathrm{C}$. Bacteriocins remained active against $L$. monocytogenes when exposed from $\mathrm{pH} 4$ to 8 and a wide temperature range; some bacteriocins were even resistant to sterilization temperatures. Bacteriocins produced were able to inhibit spoilage and pathogenic microorganisms, such as $L$. monocytogenes, $B$. cereus, and $P$. fluorescens. These results indicated that isolated bacteriocinogenic LAB present potential to be used as food biopreservatives.
\end{abstract}

Keywords: Antimicrobial compounds; autochthonous microbiota; bacteriocins; food safety.

RESUMO: A microbiota autóctone de queijos artesanais é predominantemente composta de bactérias ácido lácticas (BAL), capazes de produzir compostos antimicrobianos, como as bacteriocinas, sugerindo sua aplicação na biopreservação de alimentos. O conhecimento sobre a multiplicação de BAL e produção de bacteriocinas durante a produção e conservação de alimentos é essencial para determinar seu uso. Nesse sentido, o trabalho objetivou isolar BAL bacteriocinogênicas de vinte e um queijos artesanais do tipo Colonial, obtidos na região oeste do Paraná, Brasil, determinando as melhores condições de multiplicação e produção de bacteriocinas $\left(25^{\circ} \mathrm{C}, 30^{\circ} \mathrm{C}\right.$ e $\left.37^{\circ} \mathrm{C} / 24 \mathrm{~h}\right)$; estabilidade das bacteriocinas em diferentes faixas de $\mathrm{pH}(2,4,6,8$ e 10 por $2 \mathrm{~h}$ ) e temperatura $\left(60^{\circ} \mathrm{C} / 2 \mathrm{~h} ; 80^{\circ} \mathrm{C} / 2 \mathrm{~h} ; 121^{\circ} \mathrm{C} / 15 \mathrm{~min}\right)$. Sua atividade contra diferentes micro-organismos também foi avaliada. Um total de 34 isolados de BAL apresentou características compatíveis com a produção de bacteriocinas. A maioria desses isolados apresentou melhores resultados para a produção de bacteriocinas quando cultivadas a $25^{\circ} \mathrm{C}$ e $30^{\circ} \mathrm{C}$. As bacteriocinas permaneceram ativas contra $L$. 
monocytogenes quando expostas aos $\mathrm{pH}$ de 4 a 8 e à ampla faixa de temperatura; algumas bacteriocinas foram resistentes a temperaturas de esterilização. As bacteriocinas produzidas foram capazes de inibir micro-organismos deterioradores e patogênicos, como $L$. monocytogenes, $B$. cereus e $P$. fluorescens. Esses resultados indicaram que BAL bacteriocinogênicas isoladas apresentam potencial para serem utilizados como biopreservadores alimentares.

Palavras-chave: Bacteriocinas; compostos antimicrobianos; microbiota autóctone; segurança dos alimentos. 


\section{INTRODUCTION}

Artisanal cheeses are produced from raw milk and, as a result, most of the autochthonous microbiota is composed of lactic acid bacteria (LAB). Most LAB are safe for human consumption and can be used in food industry as starter cultures, probiotics, and biopreservatives. LAB have been recognized as valuable food biopreservatives due to their ability to synthetize antimicrobial substances, such as organic acids, hydrogen peroxide, and bacteriocins, which are able to inhibit spoilage microorganisms and foodborne pathogens (Favaro et al., 2015; Reis et al., 2012; Zacharof and Lovitt, 2012; Castellano et al., 2008; Nero et al., 2008; Deegan et al., 2006).

Bacteriocins are protein substances with inhibitory activity against closely related microorganisms (Reis et al., 2012). Due to their antimicrobial potential, bacteriocins are valuable tools for food safety, especially when it comes to cheeses produced with raw milk. Besides that, their use as biopreservatives can help to reduce the need for chemical additives and rigorous thermal treatments used in food preservation (Favaro et al., 2015).

Several intrinsic and extrinsic factors of food, such as $\mathrm{pH}$, available nutrients, water activity, microbial diversity, and storage temperature can positively or negatively influence bacteriocin production and activity (Galvez et al., 2007; Batdorj et al., 2006). Artisanal Colonial-type cheese is made from raw milk and is the main cheese produced by rural families of the southern region of Brazil. In this study, we aimed to isolate potential bacteriocinogenic LAB from artisanal Colonial-type cheeses, determining the influence of temperature in bacteriocin production. Additionally, the spectrum of activity of these compounds and their stability under different values of $\mathrm{pH}$ and temperature were also evaluated in the present study.

\section{MATERIALS AND METHODS}

Sampling and isolation of $L A B$ with antimicrobial potential

Twenty-one artisanal Colonial-type cheeses were obtained from informal farmer's markets of three cities located in the western region of the state of Parana, Brazil. Samples were transported in isothermal containers and kept under refrigeration $\left(3\right.$ to $\left.8^{\circ} \mathrm{C}\right)$ for no more than $24 \mathrm{~h}$, until the moment of analysis.

Cheese samples were homogenized at a 1:10 ratio with saline solution $(0.85 \% \mathrm{NaCl}, \mathrm{w} / \mathrm{v})$; suspensions were diluted ten-fold in saline solution, plated on the surface of multiple plates containing $10 \mathrm{~mL}$ of MRS (de Man, Rogosa and Sharpe) agar, and incubated at $37^{\circ} \mathrm{C}$ for $24 \mathrm{~h}$. All analyses were performed in duplicate.

The triple-layer method was performed in order to pre-select LAB with potential to produce antimicrobial compounds, as described by Todorov and Dicks (2004). For this purpose, Listeria monocytogenes ATCC 7644 and L. monocytogenes 422 were used as target microorganisms. Briefly, colonies on MRS agar plates were overlaid with bacteriological agar. After that, plates with less than 50 colonies were overlaid with $10 \mathrm{~mL}$ of semi-solid $\mathrm{BHI}$ agar containing active growing cells from target microorganisms (approximately $\left.10^{6} \mathrm{CFU} / \mathrm{mL}\right)$, and then incubated at $37^{\circ} \mathrm{C}$ for $24 \mathrm{~h}$. Colonies with inhibition zones larger than $2 \mathrm{~mm}$ were restreaked in MRS agar, and single colonies were submitted to Gram staining and catalase test. Gram-positive and catalase negative strains were selected as $L A B$ with antimicrobial potential. 


\section{Evaluation of bacteriocinogenic activity}

Selected isolates were grown on MRS at $30^{\circ} \mathrm{C}$ for $24 \mathrm{~h}$, and the cell-free supernatant was obtained by centrifugation at $14,000 \times \mathrm{g}$, for $15 \mathrm{~min}$. The $\mathrm{pH}$ of the supernatant was adjusted to about 6.5 with $1 \mathrm{M} \mathrm{NaOH}$ in order prevent the inhibitory effect caused by lactic acid production. After that, supernatants were treated for $10 \mathrm{~min}$ at $80^{\circ} \mathrm{C}$ to inactivate hydrogen peroxide $\left(\mathrm{H}_{2} \mathrm{O}_{2}\right)$. Then, the agar spot method was used. In this method, $10 \mu \mathrm{l}$ of each supernatant were spotted on plates containing agar $\mathrm{BHI}$ supplemented with the target microorganisms cited above (about $10^{6} \mathrm{CFU} / \mathrm{mL}$ ). Plates were incubated at $35^{\circ} \mathrm{C}$ for $24 \mathrm{~h}$, and inhibition zones around the colonies were recorded as positive results (Todorov and Dicks, 2004).

In order to confirm the proteinaceous nature of the antimicrobial compounds, cell-free supernatants from the selected isolates, obtained as described above, were treated with 0.1 $\mathrm{mg} / \mathrm{mL}$ (final concentration) proteinase $\mathrm{K}$ $1 \mathrm{mg} / \mathrm{mL}$ (Sigma-Aldrich, Darmstadt, Germany) at $30^{\circ} \mathrm{C}$ for $2 \mathrm{~h}$, followed by deactivation of the enzyme by thermal treatment at $98^{\circ} \mathrm{C}$ for $2 \mathrm{~min}$. Antimicrobial activity was determined by the agar spot test against $L$. monocytogenes ATCC 7644 and $L$. monocytogenes 422, as described above. Loss of antimicrobial activity was recorded as the positive result for bacteriocin production.

\section{Temperature optimization for bacteriocin production}

Selected isolates were recovered in $10 \mathrm{~mL}$ of MRS broth and incubated at $25^{\circ} \mathrm{C}, 30^{\circ} \mathrm{C}$, and $37^{\circ} \mathrm{C}$ for $24 \mathrm{~h}$. The cellfree supernatant was obtained by centrifugation, $\mathrm{pH}$ adjustment and thermal treatment, as described before. Then, supernatants were submitted to the critical dilution method in $10 \mathrm{mM}$ phosphate buffered saline (PBS) at $\mathrm{pH}$
6.5 (Mayr-Harting et al., 1972). Bacteriocin activity against $L$. monocytogenes ATCC 7644 and $L$. monocytogenes 422 was tested using the agar spot test (Todorov and Dicks, 2004). Bacteriocinogenic activity was expressed as arbitrary units $(\mathrm{AU} / \mathrm{mL})$, calculated as $a^{b} \times 100$, where "a" corresponded to the dilution factor, and "b" corresponded to last dilution that produced an inhibition zone greater than $2 \mathrm{~mm}$ in diameter. Supernatants were obtained based on the best conditions for bacteriocin production, and used in the tests described next.

Effect of $\mathrm{pH}$ and temperature on bacteriocin activity

The effect of $\mathrm{pH}$ on bacteriocin activity was determined by adjusting the cell-free supernatants to $\mathrm{pH} 2,4,6,8$, and 10 with sterile $\mathrm{HCl} 1 \mathrm{~N}$ or $\mathrm{NaOH} 1 \mathrm{~N}$. After $1 \mathrm{~h}$ incubation at $30^{\circ} \mathrm{C}$, the cell-free supernatants were adjusted again to $\mathrm{pH}$ 6.0. The effect of temperature on the bacteriocins was tested by incubating the cell-free supernatants at $7^{\circ} \mathrm{C}, 42^{\circ} \mathrm{C}$, $60^{\circ} \mathrm{C}$, and $80^{\circ} \mathrm{C}$ for $2 \mathrm{~h}$, as well as at $121^{\circ} \mathrm{C} / 15 \mathrm{~min}$.

In both cases, bacteriocin activity was determined by critical dilution and the agar spot test, as described above, using L. monocytogenes ATCC 7644 and $L$. monocytogenes 422 as the targets. The results were expressed as $\mathrm{AU} / \mathrm{mL}$. Cell-free supernatant with $\mathrm{pH}$ adjusted to 6.0 without any specific treatment was used as the control.

\section{Inhibitory spectrum}

To evaluate the inhibitory spectrum of bacteriocins produced by selected isolates, each supernatant obtained and treated as previously described was tested against the following targets: Staphylococcus aureus ATCC 25923, S. aureus ATCC 29213, S. aureus ATCC 23235 , S. aureus ATCC 13565, S. aureus ATCC 27664, S. aureus ATCC 19095, S. aureus ATCC 14458, S. 


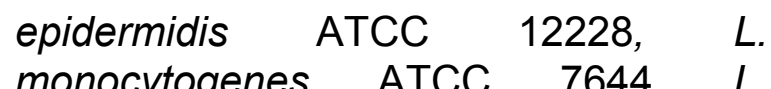
monocytogenes 422, Pseudomonas aeuruginosa ATCC 2785, $P$. fluorescens ATCC 13525, Lactobacillus sakei ATCC 15521, Bacillus cereus NVH 0173/05, B. cereus 1600075/95, Samonella Thyphimurium ATCC 14028; Samonella Enteritidis, Yersinia enterocolítica ATCC 9610, Escherichia coli ATCC 8730, and E. coli ATCC 25922. Plates containing about $10^{6} \mathrm{CFU} / \mathrm{mL}$ of each target microorganism were prepared, and the agar spot test was used (Todorov and Dicks, 2004). Plates were incubated in the best conditions for growth of each target microorganism. Inhibition zones larger than $2 \mathrm{~mm}$ were recorded as positive results.

\section{RESULTS}

From the 21 samples, 264 LAB presented antimicrobial activity against $L$. monocytogenes strains used in this study. L. monocytogenes ATCC 7644 showed to be more sensitive than the field strain (L. monocytogenes 422), as 161 BAL strains were able to inhibit Listeria monocytogenes ATCC 7644, but only 103 BAL strains were able to inhibit the $L$. monocytogenes field strain. From the 264 BAL strains with antagonist activity against $L$. monocytogenes, 34 LAB strains $(12.9 \%)$ obtained from six cheeses were confirmed as bacteriocin producers. The other BAL strains isolated presented inhibiting potential against Listeria monocytogenes probably due to other antimicrobial compounds, such as lactic acid or hydrogen peroxide.

Eighteen $L A B$ strains showed greater bacteriocin production when incubated at $25^{\circ} \mathrm{C}$, while at $30^{\circ} \mathrm{C}$ greater production was demonstrated by 20 strains, and at $37^{\circ} \mathrm{C}$, only four strains showed improved bacteriocin activity (Table 1). It was noticed that some LAB strains were able to produce the same levels of bacteriocins, when incubated at different temperatures (Table 1).

Regarding the exposure of bacteriocins to different conditions, it was noticed that $\mathrm{pH}$ changes were more influential than temperature in bacteriocin activity. In different $\mathrm{pH}$ conditions, bacteriocins produced by five $(14.7 \%)$ LAB strains (named 1, 2, 20, 21 , and 23 ) lost their activity against the target microorganisms. Differently, bacteriocins produced by five other strains $(10,11,16,27$, and 32) were able to inhibit the target microorganisms in all $\mathrm{pH}$ values analyzed, as shown in Table 2. Considering temperature, bacteriocins produced by 30 LAB strains $(88.2 \%)$ were able to inhibit $L$. monocytogenes after exposure to $7^{\circ} \mathrm{C}$, $42^{\circ} \mathrm{C}, 60^{\circ} \mathrm{C}$, and $80^{\circ} \mathrm{C}$. Additionally, bacteriocins produced by four strains $(11.8 \%)$ kept their activity even after exposure to sterilization temperatures (Table 2).

Bacteriocins produced by isolated $L A B$ strains showed a diverse spectrum of inhibition. From 34 cell-free supernatants evaluated, 13 were active against $L$. monocytogenes ATCC 7644 , and 22 were active against $L$. monocytogenes 422, while only one strain (24) produced bacteriocins able to inhibit both Listeria strains tested. Eight strains were able to produce bacteriocins active against more than one target strain tested (Table 3). From these, bacteriocins produced by strains $09,22,24,25$, and 34 were active against Gram-positive and Gramnegative targets, such as $L$. monocytogenes, $B$. cereus, $L$. sakei, and $P$. fluorescens. None of the bacteriocins produced by LAB showed activity against $S$. aureus, $S$. epidermidis, $P$. aeuruginosa, $S$. Thyphimurium, $S$. Enteritidis, Y. enterocolítica, and E. coli. 

Table 1. Bacteriocinogenic activity against $L$. monocytogenes expressed by Lactic Acid Bacteria strains isolated from artisanal cheeses incubated at different temperatures $\left(25^{\circ} \mathrm{C}\right.$, $30^{\circ} \mathrm{C}$, or $\left.37^{\circ} \mathrm{C}\right)$.

\begin{tabular}{|c|c|c|c|}
\hline \multirow{2}{*}{ Bacteriocin identification } & \multicolumn{3}{|c|}{ Incubation temperature $^{1}$} \\
\hline & $25^{\circ} \mathrm{C}$ & $30^{\circ} \mathrm{C}$ & $37^{\circ} \mathrm{C}$ \\
\hline 1 & $<100$ & $<100$ & 400 \\
\hline 2 & $<100$ & 100 & 100 \\
\hline 3 & $<100$ & 100 & 100 \\
\hline 4 & $<100$ & 100 & 100 \\
\hline 5 & $<100$ & 400 & 400 \\
\hline 6 & $<100$ & 100 & 100 \\
\hline 7 & $<100$ & 100 & $<100$ \\
\hline 8 & $<100$ & $<100$ & 100 \\
\hline 9 & $<100$ & 100 & $<100$ \\
\hline 10 & 100 & 100 & $<100$ \\
\hline 11 & 400 & 100 & $<100$ \\
\hline 12 & 100 & $<100$ & $<100$ \\
\hline 13 & 100 & 800 & $<100$ \\
\hline 14 & 800 & 1600 & $<100$ \\
\hline 15 & 400 & 800 & $<100$ \\
\hline 16 & 400 & 800 & $<100$ \\
\hline 17 & 400 & 800 & $<100$ \\
\hline 18 & 400 & 100 & $<100$ \\
\hline 19 & 400 & $<100$ & $<100$ \\
\hline 20 & 400 & 100 & $<100$ \\
\hline 21 & 400 & 100 & $<100$ \\
\hline 22 & 400 & $<100$ & $<100$ \\
\hline 23 & 400 & 100 & $<100$ \\
\hline 24 & 200 & $<100$ & 100 \\
\hline 25 & 100 & 100 & 100 \\
\hline 26 & 400 & $<100$ & $<100$ \\
\hline 27 & 400 & 400 & $<100$ \\
\hline 28 & $<100$ & 400 & $<100$ \\
\hline 29 & 100 & 100 & $<100$ \\
\hline 30 & 100 & 100 & $<100$ \\
\hline 31 & 100 & $<100$ & $<100$ \\
\hline 32 & 400 & 100 & $<100$ \\
\hline 33 & 100 & 100 & $<100$ \\
\hline 34 & 100 & 100 & $<100$ \\
\hline
\end{tabular}

${ }^{1}$ Quantification of bactericinogenic activity expressed as Arbitrary Units per milliliter (AU/mL).

\section{DISCUSSION}

Several intrinsic and extrinsic factors in foods can influence $L A B$ activity by reducing or increasing the production of antimicrobial compounds, especially bacteriocins. Selection of well-adapted strains for food production and storage conditions are essential for successful use of LAB as biopreservation tools (Galvez et al., 2007).

Among storage factors during food production, temperature is important to be considered, as it can directly influence LAB growth, metabolism, and bacteriocin production. LAB strains isolated in this study showed different behaviors when cultured at different temperatures, and it was noticed that at $25^{\circ} \mathrm{C}$ and $30^{\circ} \mathrm{C}$, bacteriocin production was greater than at $37^{\circ} \mathrm{C}$. These results corroborate findings about higher levels of bacteriocin production by L. plantarum cultured at $30^{\circ} \mathrm{C}$ than at $37^{\circ} \mathrm{C}$ (Todorov and Dicks, 2006). However, it was observed by other authors that $30{ }^{\circ} \mathrm{C}$ and $37{ }^{\circ} \mathrm{C}$ are better temperatures for bacteriocin production in $L$. plantarum, 


$\begin{array}{lll}\text { Lactococcus lactis, Enterococcus } & \text { (Cavicchioli et al., 2015; Todorov et al., } \\ \text { durans, and Enterococcus faecium 2010; Todorov, 2008). }\end{array}$

Table 2. Effects of $\mathrm{pH}\left(2,4,6,8\right.$, and 10) and temperature $\left(7,42,60,80\right.$, and $\left.121^{\circ} \mathrm{C}\right)$ on bacteriocinogenic activity expressed by 34 LAB strains isolated from artisanal cheeses using $L$. monocytogenes as the target microorganism.

\begin{tabular}{|c|c|c|c|c|c|c|c|c|c|c|}
\hline \multirow{2}{*}{$\begin{array}{l}\text { Bacteriocin } \\
\text { identification }\end{array}$} & \multicolumn{5}{|c|}{$\mathrm{pH}(\mathrm{AU} / \mathrm{mL})^{1}$} & \multicolumn{5}{|c|}{ 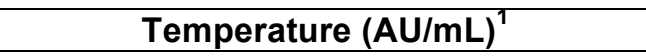 } \\
\hline & 2 & 4 & 6 & 8 & 10 & $7^{\circ} \mathrm{C}$ & $42^{\circ} \mathrm{C}$ & $60^{\circ} \mathrm{C}$ & $80^{\circ} \mathrm{C}$ & $121^{\circ} \mathrm{C}$ \\
\hline 1 & $<100$ & $<100$ & $<100$ & $<100$ & $<100$ & 1600 & 1600 & 1600 & 800 & $<100$ \\
\hline 2 & $<100$ & $<100$ & $<100$ & $<100$ & $<100$ & 1600 & 800 & 1600 & 800 & $<100$ \\
\hline 3 & $<100$ & $<100$ & 100 & $<100$ & $<100$ & 800 & 400 & 1600 & 800 & $<100$ \\
\hline 4 & $<100$ & $<100$ & 100 & 100 & 100 & $<100$ & 800 & 1600 & 800 & $<100$ \\
\hline 5 & $<100$ & 100 & $<100$ & $<100$ & $<100$ & 800 & 800 & 1600 & 800 & $<100$ \\
\hline 6 & $<100$ & $<100$ & 100 & 100 & $<100$ & 400 & 400 & 800 & 1600 & $<100$ \\
\hline 7 & $<100$ & 100 & 100 & 100 & 100 & 400 & 800 & 800 & 800 & $<100$ \\
\hline 8 & $<100$ & $<100$ & 100 & $<100$ & $<100$ & 800 & 100 & 100 & 100 & $<100$ \\
\hline 9 & $<100$ & 100 & 100 & 100 & 100 & 100 & 800 & 400 & 800 & 200 \\
\hline 10 & 100 & 100 & 100 & 100 & 100 & 800 & 800 & 400 & 400 & 400 \\
\hline 11 & 100 & 100 & 100 & 400 & 100 & 200 & 200 & 200 & 100 & $<100$ \\
\hline 12 & 100 & $<100$ & 100 & 100 & 100 & 100 & 100 & 100 & $<100$ & $<100$ \\
\hline 13 & $<100$ & $<100$ & 100 & 100 & 100 & 200 & 100 & 200 & 100 & $<100$ \\
\hline 15 & $<100$ & 100 & $<100$ & 100 & $<100$ & 200 & 200 & 200 & 100 & $<100$ \\
\hline 16 & 100 & 100 & 100 & 100 & 100 & 200 & 100 & 100 & 100 & $<100$ \\
\hline 17 & $<100$ & 100 & 100 & 100 & 100 & 200 & 100 & 100 & 100 & $<100$ \\
\hline 18 & $<100$ & 100 & 100 & 100 & 100 & 100 & 100 & 100 & 100 & $<100$ \\
\hline 19 & $<100$ & 100 & 100 & 100 & 100 & 100 & 100 & 100 & 100 & $<100$ \\
\hline 20 & $<100$ & $<100$ & $<100$ & $<100$ & $<100$ & 200 & 400 & 200 & 200 & $<100$ \\
\hline 21 & $<100$ & $<100$ & $<100$ & $<100$ & $<100$ & 200 & 100 & 200 & 100 & $<100$ \\
\hline 22 & $<100$ & 100 & 400 & 100 & 100 & 100 & 100 & 100 & 100 & $<100$ \\
\hline 23 & $<100$ & $<100$ & $<100$ & $<100$ & $<100$ & 200 & 200 & 200 & 200 & $<100$ \\
\hline 24 & $<100$ & $<100$ & $<100$ & 100 & 100 & 400 & 800 & 800 & 200 & 200 \\
\hline 25 & $<100$ & $<100$ & 100 & $<100$ & $<100$ & 400 & 800 & 400 & 400 & 400 \\
\hline 26 & $<100$ & $<100$ & 100 & $<100$ & $<100$ & 200 & 100 & 200 & 200 & $<100$ \\
\hline 27 & 100 & 100 & 100 & 100 & 100 & 200 & 200 & 200 & 200 & $<100$ \\
\hline 28 & $<100$ & 100 & 100 & 100 & $<100$ & 200 & 100 & 100 & 200 & $<100$ \\
\hline 29 & 100 & 100 & 100 & 100 & $<100$ & 200 & 200 & 200 & 200 & $<100$ \\
\hline 30 & 100 & 100 & 100 & 100 & $<100$ & 200 & 200 & 200 & 200 & $<100$ \\
\hline 31 & 100 & 100 & 100 & 100 & $<100$ & 200 & 100 & 200 & 200 & $<100$ \\
\hline 32 & 100 & 100 & 100 & 100 & 100 & 200 & 200 & 200 & 100 & $<100$ \\
\hline 33 & $<100$ & 100 & 100 & 100 & $<100$ & 200 & 200 & 400 & 100 & $<100$ \\
\hline 34 & $<100$ & 100 & 100 & $<100$ & 100 & 100 & 100 & 100 & $<100$ & $<100$ \\
\hline
\end{tabular}

'Results expressed as Arbitrary Units per milliliter (AU/mL)

The stability of bacteriocins produced by LAB can also be influenced by intrinsic and extrinsic factors of different types of food, such as $\mathrm{pH}$, temperature, composition, and resident microbiota (Galvez et al., 2007). The $\mathrm{pH}$ can exert an important influence in bacteriocin activity, which may be variable according to the producing species and the target microorganism, as observed by different authors. In a study performed to evaluate the influence of $\mathrm{pH}$ on bacteriocinogenic activity against $L$. monocytogenes, authors observed greater inhibitory effect at $\mathrm{pH}$ between 4 and 6 (Furtado et al., 2014). Similar results were observed for bacteriocin HV219, produced by Lactococcus lactis ssp. lactis, which presented greater activity against $E$. faecium HKLHS and E. faecalis E88 in $\mathrm{pH}$ between 2 to 6 (Todorov and Dicks, 2006). The bacteriocin AMA-K, produced by Lactobacillus plantarum, 
was more effective in inhibiting $L$. innocua, L. ivanovii subsp. Ivanovii, and L. monocytogenes Scott A when $\mathrm{pH}$ was adjusted to 7, while bacteriocins produced by Lactococcus sp. and
Enterococcus sp. isolated from goat milk were able to keep their activity in $\mathrm{pH}$ varying from 2 to 10 (Cavicchioli et al., 2016; Todorov, 2008).

Table 3. Inhibitory spectrum of bacteriocins produced by lactic acid bacteria (LAB) strains isolated from artisanal cheeses with simultaneous activity against more than one target microorganism tested.

\begin{tabular}{ccccccc}
\hline \multirow{2}{*}{$\begin{array}{c}\text { Bacterioci } \\
\mathbf{n}\end{array}$} & \multicolumn{5}{c}{ Bacteriocinogenic activity against the target microorganisms tested } \\
\cline { 2 - 7 } & LM & LM-UFV & BCNVH & BC & LS & PF \\
\hline 7 & + & - & + & + & - & - \\
8 & + & - & + & + & - & - \\
9 & + & - & + & + & + & + \\
10 & + & + & + & + & - & + \\
22 & - & + & + & + & - & + \\
24 & + & - & + & + & - & + \\
25 & + & - & + & + & + \\
34 & + & + & + &
\end{tabular}

In our study, bacteriocin activity against $L$. monocytogenes remained stable in from $\mathrm{pH} 4$ to 8 , indicating that despite loss of activity in extreme conditions, bacteriocins produced by $\mathrm{LAB}$ strains were active in a wide range of $\mathrm{pH}$. This result indicates that the acid conditions found in fermented foods may not affect bacteriocin activity and, in some cases, could even enhance its effect, highlighting an important finding for food technology, especially dairy products. Temperature may also act as a determinant factor in bacteriocin activity. Bacteriocins produced by $L A B$ in this study remained active after exposure to temperatures from $7^{\circ} \mathrm{C}$ up to $80^{\circ} \mathrm{C}$, and similar to findings were reported by Cavicchioli et al. (2015). In addition, bacteriocins produced by four strains remained active even after being exposed to $121^{\circ} \mathrm{C}$, showing the high stability of these compounds. Most bacteriocins are considered thermostable, resisting thermal treatment at high temperatures, such as bacteriocin DF04Mi, and nisin, produced by Lactococcus lactis (Furtado et al., 2014; Noonpakdee et al., 2003). The stability of bacteriocins in different conditions may be a good standard to determine their use as food biopreservatives under several processing conditions, including pasteurization and other thermal treatments; addition of acids; freezing; or prolonged storage periods (Batdorj et al., 2006).

Bacteriocins produced by LAB are usually effective against closely related microorganisms, and the activity against L. monocytogenes, Staphylococcus aureus, Lactobacillus sp., and other Gram-positive microorganisms has been constantly reported. Although not usual, some recent studies also demonstrated the inhibitory potential of bacteriocins produced by LAB against Gram-negative species, such as Escherichia coli, Salmonella Typhimurium, Shigella dysenteriae, Pseudomonas aeruginosa, and Klebsiella pneumoniae (Zouhir et al., 2011; Cheikhyoussef et al., 2010; Gong et al., 2010). Besides antibacterial activity, some bacteriocins were also reported as inhibitory compounds against some viruses and some yeast genera, such as Candida and Saccharomyces (Todorov et al., 2005; 
Atanassova et al., 2003). In this context, is important to highlight that bacteriocins produced by five LAB strains $(9,22,24$, 25 , and 34 ) in this study presented a broad spectrum of activity, and were able to inhibit Gram-positive microorganisms, such as $L$. monocytogenes, $B$. cereus, and $L$. sakei, as well as Gram-negative microorganisms, such as $P$. aeruginosa.

\section{CONCLUSIONS}

Artisanal Colonial-type cheeses produced in the western region of the state of Parana can be considered important sources of bacteriocinogenic $L A B$. The antimicrobial substances produced by these strains were active in different processing conditions and against spoilage and pathogenic microorganisms, such as $L$. monocytogenes and Pseudomonas fluorescens. Additional studies are necessary to identify and characterize the strains and the antimicrobial substances they produce in order to evaluate their potential as alternative tools for food biopreservation.

\section{REFERENCES}

ATANASSOVA, M.; CHOISET, Y.; DALGALARRONDO, $M$. et al. Isolation and partial biochemical characterization of a proteinaceous anti-bacteria and anti-yeast compound produced by Lactobacillus paracasei subsp. Paracasei strain M3. International Journal of Food Microbiology, v. 87, p. 63-73, 2003.

BATDORJ, B.; DALGALARRONDO, M.; CHOISET, Y. et al. Purification and characterization of two bacteriocins produced by lactic acid bacteria isolated from Mongolian airag. Journal of Applied Microbiology, v. 101, p. 837848, 2006.
CASTELLANO, P.; BELFIORE, S.; FADDA, $S$. et al. A review of bactericinogenic lactic acid bacteria used as bioprotective cultures in fresh meat produced in Argentina. Meat Science, v.79, p. 483-499, 2008.

CAVICCHIOLI, V.Q.; DORNELLAS, W.S.; PERIN, L.M. et al. Genetic Diversity and Some Aspects of Antimicrobial Activity of Lactic Acid Bacteria Isolated from Goat Milk. Applied Biochmistry and Biotecnology, v. 175, n. 6, p. 28062822, 2015.

CHEIKHYOUSSEF, A.; CHEIKHYOUSSEF, N.; HAIQUIN, C. et al. Bifidin I - A new bacteiocin produced by Bifdobacterium infantis BCRC 14602: Purification and partial amino acid sequence. Food Control, v. 21, p. 746753, 2010.

DEEGAN, L.H.; COTTER, P.D.; HILL, C. et al. Bacteriocins: Biological tools for bio-preservation and shelf-life extension. International Dairy Journal, v. 16, p. 1058-1071, 2006.

FAVARO L., PENNA A.L.B.; TODOROV, S.D. Bacteriocinogenic LAB from cheeses e Application in biopreservation? Food Science \& Technology, v.41, n.1, p.37-48, 2015; 41:37-48.

FURTADO, D.N.; TODOROV, S.D.; LANDGRAF, M. et al. Bacteriocinogenic Lactococcus

lactis subsp. lactis DF04Mi isolated from goat milk: Characterization of the bacteriocin. Brazilian Journal of Microiology, v. 45, n. 4, p. 1541-1550, 2014.

GALVEZ, A.; ABRIOUEL, H.; LOPEZ, R.L. et al. Bacteriocin-based strategies for food biopreservation. International Journal Food Microbiology, v. 120, p. 51-70, 2007.

GONG, H.S.; MENG, X.C.; WANG, H. Plantaricin $M G$ active against Gram- 
negative bacteria produced by Lactobacillus plantarum KLDS1.0391 isolated from "Jiaoke", a traditional fermented cream from China. Food Control, v. 21, p. 89-96, 2010.

MAYR-HARTING, A.; HEDGES, A.J.; BERKELEY, R.C.W. Methods for studying bacteriocins. In: NORRIS, J. R.; RIBBONS, D. W. (Eds.) Methods in Microbiology. New York: Academic Press, 1972. v. 7a, p. 313-342.

NERO, L.A.; MATTOS, M.R.; BARROS, M.A.F. et al. Listeria monocytogenes and Salmonella spp. in Raw Milk Produced in Brazil: Occurrence and Interference of Indigenous Microbiota in their Isolation and Development. Zoonoses and Public Health, v. 55, p. 299-305, 2008.

NOONPAKDEE, SANTIVARANGKNA, W.; JUMRIANGRIT, $P$. et al. Isolation of nisin-producing Lactococcus lactis WNC 20 strain from nham, a traditional Thai fermented sausage. International Journal of Food Microbiology, v. 81, p. 137-145, 2003.

REIS, J.A.; PAULA, A.T.; CASAROTTI, S.N. et al. Lactic Acid Bacteria Antimicrobial Compounds: Characteristics and Applications. Food Engineering Review, v.4, p.124-140, 2012.

TODOROV, S.D.; DICKS, L.M.T. Effect of medium components on bacteriocin production by Lactobacillus plantarum strains ST23LD and ST341LD, isolated from spoiled olive brine. Microbiological Research, v. 161, p. 102-108, 2006.

TODOROV, S.D.; DICKS, L.M.T. Screening of Lactic-Acid Bacteria from South African Barley Beer for the Production of Bacteriocin-like compounds. Folia Microbiologica, v. 49, n. 4, p. 406-410, 2004.
TODOROV, S.D.; WACHSMAN, M.; TOMÉ, E. et al. Characterization of an antiviral pediocin-like bacteriocin produced by Enterococcus faecium. Food Microbiology, v. 27, p. 869-879, 2010.

TODOROV, S.D.; WACHSMAN, M.B.; KNOETZE, $\mathrm{H}$. et al. An antibacterial an antiviral peptide produced by Enterococcus mundtii ST4V isolated from soya beans. International Journal of Antimicrobial Agents, v. 25, p. 508513, 2005.

TODOROV, S.D. Bacteriocin production by Lactobacillus plantarum AMA-K isolated from Amasi, a Zimbabwean fermented milk product and study of the adsorption of bacteriocin AMA-K to Listeria sp. Brazilian Journal of Microbiology, v. 39 , n. 1, p. 178-187, 2008.

ZACHAROF, M.P.; LOVITT, R.W. Bacteriocins Produced by Lactic Acid Bacteria A Review Article. APCBEE Procedia, v. 2, p. 50-56, 2012.

ZOUHIR, A.; KHEADR, E.; FLISS, I. et al. Partial purification and characterization of two bacteriocin-like inhibitory substances produced by bifdobacteria. African Journal of Microbiology Research, v. 5, n. 4, p. 411-418, 2011. 